\title{
Pengaruh Kompensasi dan Kompetensi terhadap Kinerja pegawai Kejaksaan Tinggi Sulawesi Selatan
}

\author{
Dicky Zulkarnain Rona Gah ${ }^{1}$, Andi Hendra Syam² \\ Manajemen, STIM LPI Makassar \\ DOI : https://doi.org/10.37531/ecotal.v3i1.118
}

\begin{abstract}
Penelitian ini bertujuan untuk Untuk mengetahui seberapa besar kompensasi berpengaruh terhadap kinerja pegawai kejaksaan tinggi sulawesi selatan dan Untuk mengetahui seberapa besar kompetensi berpengaruh terhadap kinerja pegawai kejaksaan tinggi sulawesi selatan.

Pengambilan Sampel dalam penelitian ini digunakan sebanyak 42 responden. teknik pengumpulan datanya adalah dengan menggunakan kuesioner yang dibagikan kepada responden. adapun Variabel penelitian adalah Kompensasi (X1), Kompetensi (X2), dan kinerja Pegawai (Y). penelitian ini menggunakan analisis validitas dan kuantitatif,untuk menguji tingkat realibilitasnya dengan menggunakan cronbach Alpha dan kemudian data di olah dengan Analisis Regresi Liniear Berganda. Pengujuan Hipotesis menggnakan Uji t dengan taraf signifikansi 5\%. penelitian ini menggunakan alat bantu SPSS Versi 25. Dari hasil analisis regresi linear berganda menunjukan bahwa Kinerja Pegawai di pengaruhi oleh variable Kompensasi dan Kompetensi. Hasil dari Determinasi (R2) satu variable terikat. Yaitu sebesar 0.970, yang artinya variable kinerja mampu menjelaskan kinerja pegawai sebesar 97\% sementara sisanya 3\% dipengaruhi oleh factor variable lain yang tidak diteliti. dari hasil perhitungan Uji $t$ dapat dilihat bahwa variable Kompensasi dan Kompetensi secara parsial Berpengaruh terhadap kinerja pegawai.
\end{abstract}

Keywords : Kompensasi dan Kompetensi, Kinerja pegawai.

Corresponding Author :

E-mail address: dickyzulkarnain@stim-lpi.ac.id (Jln. Bung KM.32 Tamalanrea, Makassar 90245, Indonesia)

"Received 08 December 2021, Accepted 12 January 2021, Published 29 January 2022" 
Dicky Zulkarnain Rona Gah ${ }^{\circledR}$, Andi Hendra Syam²

Pengaruh Kompensasi dan Kompetensi terhadap Kinerja pegawai Kejaksaan Tinggi Sulawesi Selatan......

DOI : https://doi.org/10.37531/ecotal.v3i1.118

\section{Pendahuluan}

Pegawai merupakan penggerak institusi, sehingga jika kinerja pegawai meningkat, maka tentunya juga kinerja organisasi juga akan meningkat. Sehingga dalam mencapai kinerja terbaik, organisasi berkepentingan melaksanakan penilaian terhadap pelaksanaan tugas pekerjaan yang dihasilkan oleh para pegawai sesuai dengan rangkaian sistem yang berlaku dalam sebuah organisasi. Namun, selama ini banyak instansi pemerintahan yang memiliki produktivitas pegawai yang rendah dan juga sulitnya dilaksanakan pengukuran kinerja pegawai, hal tersebut disebabkan karena pegawai yang belum memiliki kompetensi yang memadai (Manullang dkk, 2020 : 107). Peningkatan kompetensi pada pegawai sangat diperlukan guna mendukung kemampuan kerja sekaligus menentukan tingkat kinerja yang akan dihasilkan oleh para pegawai. Sehingga semkain tinggi kompetensi, maka tentunya semakin tinggi pula kinerja pegawai.

Kompensasi menjadi pendorong utama pegawai atau karyawan dalam bekerja, sebab dengan kompensasi berupa finansial para karyawan dapat memenuhi kebutuhannya. Namun, kompensasi yang diterima karyawan belum memenuhi. Masalah kompensasi sangat sensitive karena menjadi pendorong seseorang guna bekerja yang berpengaruh terhadap kinerja.

Kompetensi sumber daya manusia memiliki peran dalam peningkatan kinerja pegawai. Konsep pada kompetensi memiliki peran penting dalam sebuah kinerja pegawai, sebab keberhasilan sebuah organisasi menjadi pekerjaan yang penting dalam mewujudkan tujuan yang ingin dicapai.

Kompetensi juga merupakan faktor yang mempengaruhi kinerja pegawai. Selanjutnya peningkatan kinerja secara optimal bagi pegawai pada Kejaksaan Tinggi Sulawesi Selatan tidaklah mudah untuk diaplikaskan secara utuh. Hal tersebut diakibatkan oleh adanya kendala eksternal dan internal pada tugas pokok dan fungsi pegawai yang terjadi dalam melaksanakan berbagi pembenahan dan perbaikan terhadap kualitas sumber daya manusia dari pegawai, khususnya peningkatan kompetensi pegawai.

Fenomena yang terkait dengan kompetensi bahwa kinerja yang ditunjukkan oleh setiap pegawai pada Kejaksaan Tinggi Sulawesi Selatan masih perlu ditingkatkan. karena belum memperlihatkan hasil yang optimal. Ini disebabkan karena pengetahuan yang dimiliki oleh pegawai tidak sepenuhnya sesuai dengan tugasnya. Begitu pula dengan keterampilan yang dimiliki oleh setiap pegawai belum memperlihatkan keterampilan yang handal, cakap, dan ahli dalam mengembangkan dan memajukan aktivitas kerjanya. Disisi lain, sikap yang dimiliki setiap 
Dicky Zulkarnain Rona Gah ${ }^{\circledR}$, Andi Hendra Syam²

Pengaruh Kompensasi dan Kompetensi terhadap Kinerja pegawai Kejaksaan Tinggi Sulawesi Selatan.....

DOI : https://doi.org/10.37531/ecotal.v3i1.118

pegawai belum sepenuhnya dapat meningkatkan kinerja pegawai Kejaksaan Tinggi Sulawesi Selatan.

Sehubungan dengan uraian yang telah dijelaskan, maka kompensasi dan kompetensi sangat penting bagi setiap organisasi guna melaksanakan pembenahan dalam manajemen kinerja untuk menghasilkan kinerja pegawai yang optimal. Untuk itu, timbal balik atau tindak lanjut mengenai perubahan-perubahan dalam organisasi sumber daya manusia untuk menigkatkan kinerja pegawai menjadi percepatan (acceleration) dalam pemenuhan target yang diinginkan sesuai dengan pemberian kompensasi dan peningkatan kompetensi pegawai.

Kompensasi sangat penting bagi pegawai itu sendiri sebagai individu karena besarnya kompensasi merupakan sebuah pencerminan atau ukuran nilai pekerjaan pegawai itu sendiri. Sebaliknya, besar kecilnya kompensasi dapat mempengaruhi dan kinerja pegawai. Apabila kompensasi diberikan secara cepat dan benar para pegawai akan memperoleh kepuasan kerja dan termotivasi untuk organisasi. Sejalan dengan pemahaman tersebut, maka fenomena yang terjadi pada Kejaksaan Tinggi Sulawesi Selatan mengenai kinerja pegawai masih perlu ditingkatkan karena belum memadai sesuai dengan fungsinya baik dibidang administrasi maupun teknis sehingga tugas dan fungsi pelayanan kepada masyarakat belum sepenuhnya berjalan optimal.

Kantor Kejaksaan Tinggi Sulawesi Selatan merupakan sebuah instansi pemerintah, yang dituntut dalam mendapatkan penyelenggaraan tugas-tugas dan juga kegiatan secara berdayaguna dan berhasil guna sehingga dapat berhasil menunjukkan citra organisasi pemerintah yang bermutu dan berkualitas. Kejaksaan Tinggi Sulawesi Selatan merupakan lembaga Negara yang melaksanakan kekuasaan negara, khususnya di bidang penuntutan serta sebagai badan yang memiliki wewenang dalam penegakan hukum dan keadilan. Dengan adanya tugas berat ini, maka Kejaksaan Tinggi Sulawesi Selatan harus bisa meningkatkan pelayanan organisasi secara keseluruhan demi memaksimalkan sumber daya yang ada dalam organisasi guna melakukan pekerja yang lebih baik.

\section{Kajian Literatur}

\section{Kompensasi}

Kompensasi merupakan segala sesuatu yang telah diterima oleh pekerja sebagai balas jasa atas pekerjaan mereka. Kompensasi merupakan bentuk pembayaran dalam bentuk manfaat dan juga 
Dicky Zulkarnain Rona Gah ${ }^{\circledR}$, Andi Hendra Syam²

Pengaruh Kompensasi dan Kompetensi terhadap Kinerja pegawai Kejaksaan Tinggi Sulawesi Selatan.....

DOI : https://doi.org/10.37531/ecotal.v3i1.118

insentif guna sebagai motivasi karyawan agar tetap produktif dalam melakukan pekerjaan (Handoko, 2014 : 5).

Kompensasi merupakan pendapatan seseorang yang diperoleh dari perusahaan dari hasil pekerjaan yang sudah dilaksanakan pegawai sebagai bentuk apresiasi perusahaan. Kompensasi adalah segala bentuk pendapatan yang berbentuk uang, barang langsung atau tidak langsung sebagai imbalan atas jasa yang diberikan kepada perusahaan terhadap karyawan (Lestari dkk, 2021 : 4). Kompensasi merupakan semua pendapatan yang berbentuk uang atau barang langsung yang diterima karyawan sebagai imbalan atau jasa yang diberikan kepada instansi atau perusahaan.

Pemberian kompensasi adalah salah satu pelaksanaan fungsi dalam manajemen sumber daya manusia yang berhubungan dengan semua jenis pemberian pengahrgaan individual sebagai pertukaran dalam melaksanakan tugas keorganisasian. Pemberian kompensasi haruslah adil dan layak bagi seorang pegawai atau karyawan. Artinya, adil dan layak merupakan bahwa sedapat mungkin kompensasi atau gaji yang diterima kelangsungan hidup karyawan dan pemberian kompensasi itu harus pula berdasarkan pada dasar kecilnya tanggung jawab dan risiko dari masing-masing pekerjaan sehingga mampu meningkatkan kinerja pegawai atau karyawan (Yulandri, 2020:

\section{Bentuk-bentuk Kompensasi}

Kompensasi Langsung

Menurut Sumainah dkk (2016:180) membagi antara kompensasi langsung dan kompensasi tidak langsung. Kompensasi langsung (direct compensation) merupakan sebuah bayaran yang diperoleh seorang dalam bentuk gaji, upah, bonus, dan komisi.

\section{Gaji}

Gaji merupakan balas jasa dalam bentuk uang yang diterima karyawan atau pegawai sebagai konsekuensi dari kedudukannya sebagai seorang pegawai yang telah menyumbangkan tenaga dan fikirannya guna tercapai tujuan dari tempat ia bekerja.

Upah

Upah adalah imbalan finansial langsung yang dibayarkan kepada karyawan berdasarkan jam kerja, jumlah barang yang dihasilkan atau banyaknya pelayanan yang diberika.

Insentif/Bonus 
Dicky Zulkarnain Rona Gah ${ }^{\circledR}$, Andi Hendra Syam²

Pengaruh Kompensasi dan Kompetensi terhadap Kinerja pegawai Kejaksaan Tinggi Sulawesi Selatan.....

DOI : https://doi.org/10.37531/ecotal.v3i1.118

Insentif adalah imbalan langsung yang dibayarkan kepada karyawan karena kinerja melebihi standar yang ditentukan.

\section{Kompensasi Tidak Langsung}

Kompensasi tidak langsung merupakan semua pembayaran keuangan tak langsung yang diterima oleh seorang karyawan guna melanjutkan pekerjaan dengan perusahaan.

Tunjangan yang menghasilkan penghasilan (income) seperti tunjangan keamanan social dan pension menggatikan penghasilan pada waktu pension, kontuinitas gaji dan program bagi yang tidak mampu atau cacat yang jangka pendek dan jangka panjang menggatikan penghasilan yang hilang karena sakit atau cacat.

Program tunjangan yang dapat dipandang sebagai kesempatan bagi karyawan. Hal tersebut dapat meliputi mulai dari pembayaran biaya kuliah sampai liburan dan hari besar.

Fasilitas adalah tunjangan yang diterima oleh eksekutif yang mmepunyai kaitan dengan posisi dan status mereka dalam perusahaan.

\section{Kompotensi}

Secara harfiah kompetensi berasal dari kata competence yang memiliki arti kecapakan, kemampuan dan juga suatu wewenang. Sedangkan secara etimologi, kompetensi diartikan sebagai dimensi perilaku kehalian atau keunggulan seorang pemimpin atau staf yang memiliki keterampilan, pengetahuan dan juga perilaku yang baik. Kompetensi merupakan sebuah kemampuan guna menjalankan sebuah pekerjaan yang didasarkan atas keterampilan dan juga ilmu pengetahuan serta adanya dukungan oleh sikap kerja yang dituntut oleh pekerjaa tersebut (Candra dan Fatimah, $2020: 819$ )

Kompetensi merupakan kapasitas dari pegawai atau karyawan yang sesuai dengan ketetapan perusahaan dan juga tuntutan pekerjaan yang mengacu pada perilaku, sehingga akan membawa hasil yang diinginkan. Dengan kata lain, bahwa kompetensi merupakan hal-hal yang bisa membantu seseorang guna melaksanakan tugasnya dengan baik. Kompetensi didefinisikan sebagai sebuah karakteristik dasar dari seseorang yang memungkinkannya memberikan kinerja yang unggul dalam pekerjaan, situasi dan juga peran tertentu (Castana dan Widodo, 2021 : 3). 
Dicky Zulkarnain Rona Gah ${ }^{\circledR}$, Andi Hendra Syam²

Pengaruh Kompensasi dan Kompetensi terhadap Kinerja pegawai Kejaksaan Tinggi Sulawesi Selatan......

DOI : https://doi.org/10.37531/ecotal.v3i1.118

Kompetensi adalah suatu potensi dalam diri pegawai yang dapat membantu perusahaan dalam memperoleh keuntungan yang optimal. Kompetensi dapat juga dikatakan salah satu faktor yang memiliki pengaruh pada kinerja. Jika kompetensi diperhatikan maka akan mampu memnghasilkan budaya kinerja yang baik. Banyak kompetensi yang digunakan oleh sumber daya manusia akan meningkatkan kinerja (Rahayuningsih dan Maelani, 2018 : 730). Kompetensi merupakan kapasitas dari karyawan yang sesuai dengan ketetapan perusahaan dan tuntutan pekerjaan yang mengacu pada perilaku, sehingga membawa hasil yang diinginkan. Dengan demikian, kompetensi adalah hal-hal yang dapat membantu seseorang guna melaksanakan tugasnya dengan baik (Manda, 2018).

\section{Kinerja Pegawai}

Kinerja merupakan sebuah hasil seseorang secara keseluruhan selama periode tertentu di dalam melakukan tugas, seperti standar hasil kerja, sasaran kriteria atau target yang sudah ditentukan sebelumnya dan juga telah disepakati secara bersama (Putri dkk, 2021 : 3). Kinerja adalah sebuah proses yang dapat diukur dalam waktu tertentu berdasarkan ketentuan dan juga kesepakatan yang sudah ada. Kinerja dapat dideskripsikan dengan seberapa jauh kegagalan maupun keberhasilan dalam melaksanakan prosesnya guna mencapai visi mis organisasi, tujuan serta sasaran tujuan organisasi maupun perusahaan (Nurwin dan Frianto, 2021 : 2).

Kinerja merupakan hasil kerja secara kualitas dan kuantitas yang dicapai oleh seorang pegawai dalam melaksanakan tugasnya sesuai dengan tanggung jawab yang diberikan kepadanya (Custana dan Widodo, 2021 : 2). Kinerja merupakan succesfull role achievement yang diperoleh seseorang dari perbuatannya atau bisa dikatakan bahwa kinerja merupakan sebuah hasil kerja seseorang selama periode tertentu dibandingkan dengan kemungkinan (Agus, 2014: 78).

Menurut Candra dan Fatimah (2020 : 817) menyatakan bahwa secara umum dapat dinyatakan empat aspek dari kinerja yaitu, sebagai berikut:

1) Kualitas yang dihasilkan, menerangkan tentang jumlah kesalahan, waktu, dan ketetapan dalam melaksanakan tugas.

2) Kuantitas yang dihasilkan, berkenaan dengan beberapa jumlah produk atau jasa yang dapat dihasilkan.

3) Waktu kerja menerangkan akan jumlah absen, keterlambatan, serta masa kerja yang telah dijalani individu pegawai tersebut.

4) Kerja sama menerangkan akan bagaimana individu membantu atau menghambat usaha dari teman sekerjanya. 
Dicky Zulkarnain Rona Gah ${ }^{\circledR}$, Andi Hendra Syam ${ }^{2}$

Pengaruh Kompensasi dan Kompetensi terhadap Kinerja pegawai Kejaksaan Tinggi Sulawesi Selatan......

DOI : https://doi.org/10.37531/ecotal.v3i1.118

Secara konseptual kinerja pada dasarnya bisa dilihat dari dua segi, yaitu kinerja pegawai secara individu dan juga kinerja organisasi. Kinerja pegawai merupakan hasil kerja perseorangan dalam suatu organisasi. Sedangkan kinerja organisasi merupakan totalitas hasil kerja yang telah dicapai sebuah organisasi. Kinerja pegawai dan kinerja organisasi memiliki keterkaitan erat. Sehingga tercapainya organisasi tidak dapat dilepaskan sumber daya yang dimiliki oleh organisasi yang digunakan atau dijalankan oleh pegawai yang berperan aktif sebagai pelaku dalam upaya mencapai tujuan dari organisasi.

\section{Metode Penelitian}

Metode wawancara yang digunakan guna mendapatkan data dengan cara mengajukan pertanyaan kepada unit organisasi yang bersangkutan dalam melakukan sistem kerja pegawai guna meningkatkan kinerja para pegawai. Metode kuesioner adalah cara pengumpulan data primer dari para responden yang terpilih menjadi sampel penelitian. Kuesioner disusun dengan cara mengajukan pernyataan tertutup serta pilihan jawaban untuk disampaikan kepada sampel penelitian (Sugiyono, 2019). Dalam penelitian ini menggunakan kuesioner/angket tertutup, dimana responden hanya memilih jawaban yang tersedia dalam angket tersebut dengan skala pengukuran yang digunakan adalah skala likert. Skala likert digunakan untuk mengukur sikap, pendapatan dan persepsi seseorang/kelompok tentang kejadian, gejala sosial/tanggapan. Sehingga dari pernyataan tersebut dapat disimpulkan bahwa skala likert merupakan suatu alternative pengukuran yang dapat digunakan oleh peneliti untuk mengukur suatu kejadian atau gejala sosial yang kemudian dirubah dalam bentuk angka agar mudah dalam menyimpulkan. Dalam penelitian tersebut pengumpulan data yang dipakai, ialah berupa kuesioner dengan skala model likert yang telah dimodifikasi. Skala likert adalah berupa interval yang spesifik dipakai pada lima pilihan yaitu rincian tersebut, yaitu sebagai berikut: 1 (Sangat Tidak Setuju/STS), 2 (Tidak Setuju/TS), 3 (Ragu-Ragu/ Netral), 4 (Setuju/S) serta 5 (sangat Setuju/SS). Populasi adalah wilayah generalisasi yang terdiri atas objek atau subjek yang kuantitas dan karakteristik tertentu yang ditetapkan oleh peneliti untuk mempelajari dan kemudian ditarik kesimpulannya. Jadi, populasi bukan hanya orang tetapi juga objek dan benda-benda alam lainnya. Populasi juga bukan sekedar jumlah yang ada pada objek atau subjek yang dipelajari, tetapi meliputi seluruh karakteristik atau sifat yang dimiliki oleh objek atau subjek itu (Sugiyono, 2019). Populasi dalam penelitian ini adalah seluruh Pegawai yang bekerja di kejaksaan Tinggi Sulawesi Selatan yang bagian bidang berjumlah 866 orang.

Volume 3 Issue 1 (2022)

Economics and Digital Business Review

ISSN: 2774-2563 (Online) 


\section{Hasil Penelitian dan Pembahasan}

\subsection{Analisis Regresi Linear Berganda}

Teknik analisis yang digunakan peneliti untuk memecahkan permasalahan dalam penelitian ini, peneliti menggunakan analisis regresi linier berganda. analisis regresi linier berganda diolah menggunakan bantuan program SPSS for windows release 25.0 analisis selengkapnya dapat dilihat pada table berikut.

Analisis Linier Berganda

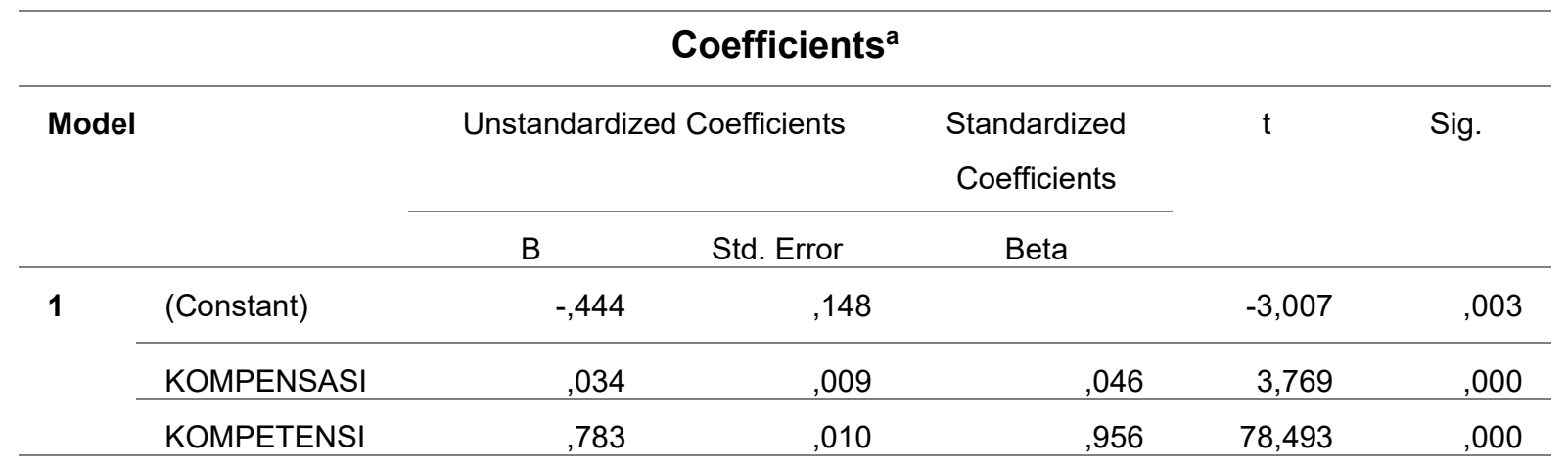

Sumber: Data hasil Olahan Penelitian spss 2021

Berdasarkan dari hasil pengolahan dan komputerisasi dengan menggunakan program SPSS versi 25.0 maka diperoleh persamaan regresi linear sederhana sebagai berikut :

$\mathrm{Y}=\beta 0+\beta 1 \mathrm{X} 1+\beta 2 \mathrm{X} 2+\mathrm{e}$

$\mathrm{Y}=0.444+0.034+0.783+0.10$

Persamaan regresi diatas dapat memperlihatkan dan dijelaskan antara variable Independent dengan variable dependen secara parsial, dari persamaan tersebut diambil kesimpulan sebagai berikut :

1. Nilai konstanta $\mathrm{a}=0.444$ menunjukkan bahwa jika kompensasi dan Kompetensi konstan atau $\mathrm{X} 1=0, \mathrm{X} 2=0$ maka Kinerja pegawai pada kantor Kejaksaan Tinggi Sulawesi selatan. menunjukkan bahwa setiap Kompensasi dan Kompetensi akan mendorong Kinerja Pegawai sebesar 0.444 satuan.

2. Nilai Koefisien regresi Kompensasi adalah 0.034 artinya jika variable Kompensasi (X1) meningkat 1\% dengan asumsi variable kompetensi (X2) dan konstanta (a) adalah 0 maka 
Dicky Zulkarnain Rona Gah ${ }^{\circledR}$, Andi Hendra Syam ${ }^{2}$

Pengaruh Kompensasi dan Kompetensi terhadap Kinerja pegawai Kejaksaan Tinggi Sulawesi Selatan.....

DOI : https://doi.org/10.37531/ecotal.v3i1.118

Kinerja pegawai pada Kator Kejaksaan Tinggi Sulawesi selatan meningkat sebesar 0.034. Hal Tersebut menunjukan bahwa variable Kompensasi yang diberikan berkontribusi positif bagi kinerja pegawai, sehingga semakin besar Kompensasi kerja yang diberikan oleh pimpinan maka semakin melambung pula kinerja pegawai.

3. Nilai koefisien regresi Kompetensi (X2) adalah 0.783 artinya jika variable kinerja pegawai (y) meningkat sebesar 1\% dengan asumsi kompensasi (X1) dan konstanta (a) adalah 0, Maka kinerja pegawai Kantor Kejaksaan Tinggi Sulawesi Meningkat sebesar 0.783. Hal tersebut menunjukan bahwa Kompetensi diberikan berkontribusi positif bagi kinerja pegawai, sehingga semakin melambung tinggi pula kinerja pegawai.

\subsection{Pembahasan}

Kompensasi

Kompensasi merupakan segala sesuatu yang telah diterima oleh pekerja sebagai balas jasa atas pekerjaan mereka. Kompensasi merupakan bentuk pembayaran dalam bentuk manfaat dan juga insentif guna sebagai motivasi karyawan agar tetap produktif dalam melakukan pekerjaan (Handoko, 2014 : 5). Dan Melalui hasil uji parsial antara Kompensasi degan kinerja pegawai memiliki pengaruh yang positif dan signifikan. yang mana diliat dari sisi saling menghargai pendapat,memgembangkan inisiatif, melakukan hubungan yang sportif, mengembangkan karir,senang menerima pendapat dari berbagai organisasi dan pimpinan,serta memberi kenyamanan untuk mempengaruhi kinerja. sehingga dikatakan Kompensasi berpengaruh positif terhadap kinerja pegawai karena hasil uji parsial Kompensasi memiliki nilai sig $0.00<$ dari 0.05 .

\section{Kompotensi}

Kompetensi merupakan kapasitas dari pegawai atau karyawan yang sesuai dengan ketetapan perusahaan dan juga tuntutan pekerjaan yang mengacu pada perilaku, sehingga akan membawa hasil yang diinginkan. Dengan kata lain, bahwa kompetensi merupakan hal-hal yang bisa membantu seseorang guna melaksanakan tugasnya dengan baik. dari hasil uji parsial Kompetensi menunjukan bahwa ada pengaruh yang signifikan Kompetensi pada terhadap kinerja pegawai untuk lebih baik. maka dengan menerapkan kemampuan dan keterampilan individu yang baik, yaitu suatu bentuk dorongan secara langsung kepada pegawai agar hasilnya menapai hasil yang yang diharapkan, maka kantor akan memiliki sumber daya manusia yang berkualitas dan berkompetensi Tinggi. 
Dicky Zulkarnain Rona Gah ${ }^{\circledR}$, Andi Hendra Syam²

Pengaruh Kompensasi dan Kompetensi terhadap Kinerja pegawai Kejaksaan Tinggi Sulawesi Selatan.....

DOI : https://doi.org/10.37531/ecotal.v3i1.118

Dari hasil uji asumsi klasik bahwa hasil penelitian ini dihasilkan berdistribusi normal dan beberapa uji asumsi klasik digunakan hasilnya berdistribusi normal, tidak terjadi korelasi di antara variabel independen, tidak terjadi heteroskedastisitas sehingga dikatakan variabel kompensasi dan kempetensi sangat besar berpengaruh terhadap kinerja pegawai kejaksaan tinggi Sulawesi selatan.

Diantara variable Kompensasi dan Kompetensi, ternyata yang paling dominan pengruhnya terhadap kinerja pegawai yaitu kompetensi. kenapa, karena variable Kompetensi memiliki thitung yang terbesar dibandingkan dengan thitung kompensasi sehingga hipotesis yang menyatakan bahwa 'variabel Kompetensi lebih dominan pengaruhny terhadap kinerja pegawai jika dibandingkan dengan Kompensasi' secara Parsial dapat diterima.

\section{Kesimpulan}

Dari Hasil analisis regresi linear berganda menunjukan bahwa kinerja pegawai di pengaruhi oleh variable kompensasi dan Kompetensi. hasil Dari Determinasi (R2) satu variable terikat Yaitu sebesar 0.970, yang artinya variable kinerja mampu menjelaskan kinerja pegawai sebesar 97\% sementara sisanya 3\% dipengaruhi oleh factor variable lain yang tidak diteliti. dari hasil perhitunga uji t dapat dilihat bahwa variabl Kompensasi dan Kompetensi secara parsial berpengaruh terhadap kinerja pegawai. Berdasarkan hasil penelitian yang telah dilakukan untuk menguji Pengaruh Kompensasi dan Kompetensi terhadap Kinerja Pegawai Pada Kantor Kejaksaan Tinggi Sulawesi Selatan, dapat disimpulkan bahwa Kompensasi Dan Kompetensi berpengaruh Positif dan Signifikan secara parsial terhadap kinerja pegawai pada kantor Kejaksaan Tinggi Sulawes Selatan. Artinya semakin tinggi tingkat kompensasi dan Kompetensi maka semakin tinggi pula tingkat Kinerja yang dimiliki oleh pegawai.

\section{Referensi :}

Adha, R. N., Qomariah, N., \& Hafidzi, A. H. (2019). Pengaruh Motivasi Kerja, Lingkungan Kerja, Budaya Kerja terhadap Kinerja Karyawan Dinas Sosial Kabupaten Jember. Jurnal Penelitian IPTEKS. Vol. 4. No. $1: 47$.

Adipratama, E., Ferdinand., F. Husnatarina. 2020. Kinerja Pegawai pada Biro Pengadaan dan Jasa Sekretariat Daerah Provinsi Kalimantan Tengah. Journal of Environment and Management. Vol. 2. No. 1 : 35-43. 
Dicky Zulkarnain Rona Gah ${ }^{\circledR}$, Andi Hendra Syam ${ }^{2}$

Pengaruh Kompensasi dan Kompetensi terhadap Kinerja pegawai Kejaksaan Tinggi Sulawesi Selatan.....

DOI : https://doi.org/10.37531/ecotal.v3i1.118

Anjani, A.2019. Pengaruh Kompetensi dan Motivasi Kerja terhadap Kinerja Karyawan. Jurnal Inspirasi Bisnis Dan Manajemen. Vol. 3. No. 1 : 1-10.

Castana dan Widodo, S. 2021. Pengaruh Kompetensi dan Kompensasi terhadap Kinerja Karyawan PT. Angkasa Pura II (Persero) Bandar Udara Halim Perdanakusuma, Jakarta. Jurnal Ilmiah MProgress. Vol. 11. No. $1: 1-12$.

Diah, S. 2017. Pengaruh Kompetensi Kerja terhadap Kinerja Karyawan di Kantor PT. Kitadin Tanggarong Seberang. e-Jorunal Administrasi Negara. Vol. 5 No. 2 : 5789-5802.

Ghozali, Imam. 2013. Aplikasi Analisis Multivariat Dengan Program SPSS 21. Edisi 7. Badan Penerbitan Universitas Diponegoro: Semarang.

Huzemah. 2020. Pengaruh Kompensasi dan Kompetensi terhadap Kinerja Pegawai pada Sekretariat DPRD Kabupaten Parigi Moutong. Jurnal Ekonomi Trend. Vol. 08. No. 02 : 38-43.

Lestari, W..F.A., I.R. Dewi., dan A. Kanivia. 2021. Pengaruh Kompensasi, Kompetensi, dan Motivasi pada Produktivitas Kerja Pegawai PT. Jasa Marga (Persero) Tbk. Cabang Palikanci. Jurnal Manajemen dan Bisnis. Vol. 3. No. 1 : 1-11.

Manullang, A. K.., T. Puspa., dan A. K. Wardini. 2020. Pengaruh Kompetensi dan Penempatan Kerja terhadap Kinerja Pegawai Negeri Sipil di Kabupaten Tapanuli Tengah. Makro, Jurnal Manajemen \& Kewirausahaan. Vol. 5. No. 2 : 107-119.

Manda, D. (2018). The Effect of Reward System and Staff Competence Towards Working Perfomance Within The Faculty of Social Science. Atlantis Press Journals, 226(Icss), 966-969. https://www.atlantis-press.com/proceedings/icss-18/25903948

Maulidiyah, N. N., T. N. Roifah., dan N. Armanto. 2021. Kompensasi dan Kepuasan Kerja sebagai Alternatif Peningkatan Kinerja Karyawan. Jurnal Al-Idarah. Vol. 2. No. 1 : 41-48.

Nurwin,J., dan A. Frianto. 2021. Pengaruh Kompetensi dan Motivasi terhadap Kinerja Karyawan Perusahaan Asuransi. Jurnal Iilmu Manajemen. Vol. 9 No. 3 : 1-10.

Putri, A., S. Nuringwahyu., dan R. N. Hardianti. 2021. Pengaruh Rekrutmen dan Seleksi Pegawai terhadap Kinerja Pegawai. JIAGABI. Vol. 1 No. 1 : 1-12.

Rahayuningsih, S., dan Melani. N. 2018. Pengaruh Kompetensi, Kompensasi dan Motivasi terhadap Kinerja Karyawan (Studi pada PT. Pisma Garment Demak Jawa Tengah. Prossiding Sendi. 726736.

Sumainah, F., B.S. Sunuharyo., dan H. N. Utami. 2016. Pengaruh Kompensasi Langsung dan Kompensasi Tidak Langsung terhadap Motivasi Kerja Karyawan dan Kinerja Karyawan. Jurnal Administasi Bisnis (JAB). Vol. 37. No. 1 : 178-187. 
Dicky Zulkarnain Rona Gah ${ }^{1 凶}$, Andi Hendra Syam²

Pengaruh Kompensasi dan Kompetensi terhadap Kinerja pegawai Kejaksaan Tinggi Sulawesi Selatan......

DOI : https://doi.org/10.37531/ecotal.v3i1.118

Sugiyono. 2019. Metode Penelitian Kuantitatif,Kualitatif, dan R\&D. (Bandung: Penerbit Alfabeta). 